folk/ed. 2021; 27(2) $106 \mathrm{Ek}$

DOI: $10.22559 /$ folklor.1743

\title{
Gösterişçi Tüketim, Sınıf, Din ve Güçlenme Ekseninde Muhafazakâr Kadınlar*
}

\author{
Conservative Women on the Axis of Conspicuous \\ Consumption, Class, Religion and Empowerment
}

\section{Gökçe Çöçel** Pınar Melis Yelsalı Parmaksız **}

$\ddot{O} z$

Gaziantep’te yaşayan, üst orta sınıftan muhafazakâr kadınların gösteriş̧̧i tüketim pratiklerine odaklanan bu makale, gündelik yaşamda özellikle kadınlar arası karşılaşmalar yoluyla sınıfın, muhafazakârlığın ve kadın deneyimlerinin dönüşümünü anlamayı amaçlar. Buradan hareketle makalede üst sinıftan muhafazakâr kadınların deneyimlerinin güçlenme ekseninde imkânı tartışılmaktadır. Çalışmanın verileri feminist bir metodoloji ile gerçekleştirilen nitel bir saha çalışması ile toplanmıştır. Saha araştırması Gaziantep’te 2019 yılında, Mart ve Eylül aylarını kapsayan altı aylık bir süre içinde, çalışmaya katılan muhafazakâr ve/veya dindar kadınlarla gerçekleştirilen, onların gündelik yaşamlarına ve deneyimlerine odaklanan 14 birebir görüşme, 27 derinlemesine görüşme ile toplamda 14 kişiden oluşan iki ayrı grupla yapılan odak grup görüşmelerine dayanmaktadır. Araştırma verileri görüşme kayıtlarından ortaya

Geliş tarihi (Received): 02.03.2021 - Kabul tarihi (Accepted): 29-04.2021

* Bu makale 27.12.2019 tarihinde Ankara Üniversitesi Sosyal Bilimler Enstitüsünde Doç. Dr. Pınar Melis Yelsalı Parmaksız danışmanlığında tamamlanan “Gaziantep’te Üst Orta Sınıftan Kadınların Tüketim Pratikleri ve Yeni Muhafazakâr Kimlik” başlıklı doktora tez çalışmasından oluşturulmuştur.

** Dr. Ankara Üniversitesi Kadın Çalışmaları Ana Bilim Dalı. cocelg@gmail.com. ORCID 0000-0003-2357-8801

*** Doç. Dr. Bahçeşehir Üniversitesi Sosyoloji Bölümü. pinarmelis.yelsaliparmaksiz@eas.bau.edu.tr. ORCID 0000-0001-7659-4077 
çıkan temalar çerçevesinde yorumlanarak analiz edilmiştir. Sonuçta üst orta s1nıftan muhafazakâr kadınların güçlenmesi, ataerkil ilişkiler bağlamında uyum ve direniş stratejilerine dikkat çeken Deniz Kandiyoti'nin ataerkil pazarlık ve Sylvia Walby'nin kadınlar üzerindeki tahakkümü farklı toplumsal sistemler içinde farklı ataerkilliklere dikkat çekerek açıklayan özel ataerkillikten kamusal ataerkilliğe geçiş kavramları kullanılarak açıklanmıştır.

Anahtar sözcükler: gösterişçi tüketim, İslam, muhafazakâr kadınlar, ataerkil pazarlık, kamusal ataerkillik

\begin{abstract}
This article focuses on the practices of conspicuous consumption of the uppermiddle-class conservative women living in Gaziantep and aims to understand the transformation of the class, conservatism, and the women's experiences through women's encounters in daily life and furthermore, discusses the possibility for women's empowerment. The data was collected through a qualitative field study by using a feminist methodology. The fieldwork took place in Gaziantep in a 6-month-period from March to September in 2019 and consists of 14 individual interviews, 27 in-depth interviews and two distinct focus groups with a total number of 14 participants. All interviews focus on the daily lives and personal experiences of the conservative/religious women who participated in the research. Research data was analysed through interpretation of the themes which emerged from the data. As a result, the empowerment of the upper-middle-class conservative women was explained through the concepts of the patriarchal bargain - a term that is coined by Deniz Kandiyoti, to refer to strategies employed by women within a system of concrete patriarchal constraints and the move from private to public patriarchy, which points out to changing forms of women's domination within different social systems as explained by Sylvia Walby.
\end{abstract}

Keywords: conspicuous consumption, Islam, conservative women, patriarchal bargain, public patriarchy

\title{
Extended abstract
}

Background: Women's subject positions in consumption are prominent because of their role in conspicuous consumption which determines the class of the family. The concept of conspicuous consumption was first used by Veblen (2015) in the 19th century to describe the leisure class in America. The concept describes the demand shown by members of this class towards luxury consumer goods and the change in their personal tastes. We claim that conspicuous consumption, experienced by conservative women concerning the demand for identity, as well as the qualities that Bourdieu (2015) resorts to in explaining the formation of class difference through economic, social, cultural, and symbolic capital. 
Research Purpose: We discovered that the studies aimed at explaining the social transformation that took place in Turkey, especially in the last two decades, involve two main orientations. The first one focuses on the formation of a new bourgeoisie class through economic processes, placing the relationship between Islamic conservatism and neo-liberalism at the center. The second type of studies, while focusing on the Islamic way of life, approach women, especially women wearing headscarves, as representatives of conservative transformation. Although these studies undoubtedly significantly contribute to the scholarship, they have some limitation. First, conservatism is often treated as a given or taken-for-granted feature of analysis. Contrarily, we found that the transformation observed in the daily lives of conservative social groups includes different conservative positions and experiences. Moreover, although the term gender is located at an important intersection, it is often treated as a one-dimensional entity and the only representative for explaining the conservative identity. This study focuses on how social actors establish conservatism and conservative identity, albeit with negotiations to a degree that exceeds beyond the fact that they are fixed identities attributed to certain social groups.

Particularly, we limit our analysis to the practices of conspicuous consumption among the upper-middle-class conservative women living in Gaziantep and aims to understand the transformation of the class, conservatism, and the women's experiences through women's encounters in daily life. From this point further, we question the possibility of women's empowerment. The article relies on the data which was collected through a qualitative field study by using a feminist methodology. The fieldwork took place in Gaziantep within a 6-month-period from March to September in 2019 and consists of 14 individual interviews, 27 in-depth interviews and two focus groups with a total number of 14 participants. All interviews focus on the daily lives and personal experiences of the conservative/religious women who participated in the research. Research data was analyzed through interpretation of the themes which emerged from the data.

Findings: As we alluded to above, conservatism cannot be treated as a fixed identity. Although the women who participated in the study were positioned as conservatives in the earlier studies as mentioned above, their conservatism and how they defined themselves constituted the point of departure of this research. While most respondents associate conservatism with religion, they did not describe themselves as conservative for a variety of reasons.

In terms of defining conservatism, appearance and clothing stood out as decisive indicators for participants. Nevertheless, while the purpose of the clothing style that the participants associated with conservatism was aimed to cover the female body and to destroy class distinctions, they felt that they were moving away from this ideal because they followed the fashion of the hijab. Moreover, the headscarf has become a means of highlighting class distinctions and thus an element of cultural capital. 
Consumption practices have a functional role in establishing and maintaining the differences between the old and new upper middle class as well as the upper-middle class from the lower classes. For the new conservatives, consumption is a luxury and, albeit excessive, act that is approved, even if it is considered a waste. On top of that, it is understood that freedom of consumption is equivalence with individual freedom, whereby consumption is legitimized for participating in modernity. Furthermore, the most important area where conspicuous consumption is exhibited is the emergent public gatherings among women. Here, 'meetings' refer to women's reception days and mevlits as religious gatherings stand out. They become places where both class attributes and religious practices are exhibited.

For almost all the women who participated in the research, there was a link between joining the upper middle class and empowerment. The experience of empowerment was explained through examples previously linked to taking part in the homogeneous public sphere of urban life, which once excluded women in headscarves, and participating in social life.

Conclusions: In the last two decades, conservatives in Turkey have had the opportunity to integrate with the market at an advanced level. What makes uppermiddle-class conservative identity new, especially for women, is the way they live, the relationship between identity and experience, and the ways of claiming subjectivity in everyday life. Since the empowerment experience described above occurred by remaining within the confines of the family and negotiating with men; peripheral readings and evaluations of this sort of transformation were incomplete. The strategy for negotiation, which can be described as women obtaining certain privileges using both adaptive and resistant strategies without directly conflicting with the patriarchal structure, can be explained by the concept of "patriarchal bargain" (Kandiyoti, 2013).

To sum up, the move of women from the private sphere where direct patriarchal control operates to the public sphere increases opportunities in terms of participation in education and employment. It can also be said that this has led to a social transformation from private patriarchy to public patriarchy (Walby, 2016) for conservative women. Although in the new public patriarchal discourse advocated by the ruling party, women continue to be defined by their traditional roles and moral attributes, the shift from private to public patriarchy offers the upper-middle-class conservative women to escape from the constraints of direct control of men in the private sphere and to participate in the public life.

\section{Giriş}

Gaziantep’te yaşayan, üst orta sınıftan muhafazakâr kadınların gösterişçi tüketim pratiklerine odaklanan bu makale, gündelik yaşamda özellikle kadınlar arası karşılaşmalar yoluyla sınıfın, muhafazakârlığın ve kadınların deneyiminin dönüşümünü anlamayı amaçlamaktadır. Kadınların tüketim içindeki özne konumları, özellikle gösterişçi tüketiminden sorumlu olarak ailenin sınıfını belirleyen rolleri nedeniyle öne çıkmaktadır. 
Araştırmanın odaklandığı bir kavram olan gösterişçi tüketim kavramı ilk olarak 19. yy 'da Amerika'daki aylak sınıfı açıklamak amacıyla Veblen (2015) tarafından kullanılmıştır. Kavram, bu sınıfın üyeleri tarafından lüks tüketim ürünlerine gösterilen talebi ve kişisel zevklerdeki değişimi tarif eder. Biz bu makalede, gösterişçi tüketim kavramını Bourdieu (2015)'nun sınıfsal farkın oluşumunu açıklarken başvurduğu ekonomik, toplumsal, kültürel ve sembolik sermaye yoluyla sınıfı kuran nitelikleriyle bağlantı kurarak kullanıyoruz. Yanı sıra, gösterişçi tüketimin muhafazakâr kadınlar tarafından kimlik ve öznellik talebiyle ilişkili olarak deneyimledikleri bir pratik olduğunu öne sürüyoruz. Buradan hareketle de, üst sınıftan muhafazakâr kadınların deneyimlerinin güçlenme ekseninde imkânını tartışmaya açıyoruz. Güçlenme kavramını ise kadınların kendileri için mümkün olan varoluş ve eyleme biçimlerini yeniden tanımladıkları ve kapsamını genişlettikleri süreçler olarak tanımlıyoruz (Mosedale, 2005: 252).

Türkiye'de özellikle de son yirmi yılda meydana gelen toplumsal dönüşümü açıklamaya yönelik çalışmaların iki ana yönelim içerdiği söylenebilir. Bunların ilki, İslami muhafazakârlık ile neo-liberalizm arasında ilişkiyi merkeze koyarak iktisadi süreçler üzerinden yeni bir burjuvazi sınıfının oluşumuna odaklanır (Adaş, 2003, 2006; Buğra, 1998, 2002; Buğra ve Savaşkan, 2015; Demiralp, 2009; Hoşgör; 2013; Özcan ve Çokgezen, 2003; Öztürk, 2013; Özoral, 2011). Yine bu ilk grup içine dâhil edebileceğimiz başka çalışmalarda ise, benzer şekilde, ekonomik alanda yaşanan dönüşümlerin, siyaset ve gündelik hayat başta olmak üzere, diğer pek çok sosyal alan ile ilişkisi, etkileşimi ve/veya bu alanlar üzerindeki etkisinin tartışıldığ görülür (Alpman, 2012; Doherty, 2007; Durak, 2012; Durakbaşa, 2010; Karakaya, 2018; Özoral, 2011; Rubin, 2005; Tuğal, 2011; Yavuz, 2006).İkinci tür çalışmalarda, İslami yaşam tarzına yönelik ilginin, muhafazakâr dönüşümün temsilleri olarak görülen kadınlara, özel olarak başörtülü kadınlara yöneldiği görülür. Muhafazakâr olarak nitelendirilen kadınların moda başta olmak üzere, çeşitli alanlardaki tüketim pratikleri, bu gruptaki çalışmalarda muhafazakârlığın ve muhafazakârların ekonomik ve siyasal alandaki dönüşümünü anlatmak açısından önemli bir kaynak/dayanak olarak ele alınmıştır (Aktaş, 2013; Balkanlığlu, 2014; Barbarosoğlu, 2006, 2013; Bilici, 2017; Erkilet, 2012; Gökarıksel ve Secor, 2008, 2010; Göle, 2017, 2016; Karakaya, 2018; Meşe, 2015; Navaro-Yaşın, 2017; Sandıkçı ve Ger, 2007; Yücebaş, 2012).

Yukarıda belirtilen çalışmalara ek olarak, yakın zamanda yapılan çalışmaların giderek daha fazla söz konusu toplumsal dönüşümün, gündelik hayat pratiklerinde karşımıza çıkan yansımalarına odaklanmaya başladığı gözlenir. Bu türden çalışmalar, hem gündelik hayatı araştırma alanına dâhil etmesi nedeniyle, hem de tek boyutlu olarak bir İslami burjuva oluşumu anlatısının ötesine geçerek, gündelik hayat içinde çeşitli şekillerde birbiriyle etkileşim içinde olan orta ve üst-orta sınıflara daha yakından bakmasıyla yenilikçi bir araştırma alanına işaret eder. Sosyal farklılıkların fiziksel mekânda ve/veya sosyal ilişkilerde nasıl kurulduğunu ve nasıl sürdürüldüğünü gösteren bu çalışmalar (Mollaer, 2016; Akçaoğlu, 2018), sınıfsal ve toplumsal 
ayrımları ve ayrışmaları açıklamak bakımından çok önemli olsa da kadınların toplumsal dönüşüm içindeki yeri ve failliği bu çalışmalarda oldukça sınırlı bir şekilde kendine yer bulmaktadır.

Yukarıda kısaca tartışılan iki temel araştırma yönelimi ile yeni ortaya çıkan araştırma alanları, Türkiye'deki muhafazakâr dönüşüm hakkında çok değerli katkılar sunmakla birlikte, bu araştırmanın ele aldığı sorunsalı açıklamak bakımından belirli sinırlılıklar taşımaktadır. Her şeyden önce, sayılan çalışmalarda muhafazakârlık çoğunlukla verili bir özellik olarak ele alınmaktadır. Oysa muhafazakâr toplumsal grupların gündelik hayatında gözlenen dönüşüm, farklı muhafazakâr konumları ve farklı deneyimleri içermektedir. Muhafazakârlık ile ilgili çalışmaların büyük bir çoğunluğunun, muhafazakârlığı tanımlamada/kavramsallaştırmada karşılaşılan güçlükler ile başladığı görülebilir. Bu anlamda muhafazakârlık kavramı yeterince açık değildir, dahası tanımlama çabaları oldukça tartışmalıdır (Beneton, 2016: 7).

Muhafazakârlık, bir ideoloji, bir dünya görüşü, bir siyaset anlayışı, bir tavır ve bir tutum gibi (Çiğdem, 2013: 13) çeşitli durumları, kimlikleri ve fikirleri tanımlayan geniş bir anlam repertuvarına karşılık gelir. Bu çalışmada, muhafazakârlığın tarihsel ve toplumsal olarak dönüşümünü temel bir varsayım olarak kabul ediyoruz. Öte yandan, muhafazakârlığı açıklamak için kullanılan din, ahlak, gelenek, modernlik, sınıf gibi kavramların anlamlarının ve muhafazakârlıkla ilişkilerinin değişken olduğunu ileri sürüyoruz. Dolayısıyla bu çalışmada, muhafazakârlığın anlamını din, gelenek, ahlak, modernlik, sınıf gibi kimlik unsurları ile gündelik deneyimler ve karşılaşmalar yoluyla açıklıyoruz. Bu çerçeve içinde cinsiyeti, yukarıda tartışılan çalışmalardaki sınırlılıkları aşmaya yönelik bir yaklaşım içinde ele alıyoruz. Sayılan çalışmalarda cinsiyet, muhafazakâr kimliği açıklamak açısından genellikle tek boyutlu ve belirli bir konumun göstereni olarak temsil edici nitelikleriyle ele alınmıştır.

Bu çalışmada, muhafazakârlığın ve muhafazakâr kimliğin, belirli toplumsal gruplara atfedilen sabit kimlikler olmasının ötesine geçerek toplumsal aktörler tarafından hangi yollarla, araçlarla ve müzakerelerle kurulduğuna odaklanıyoruz. Bu çalışmada muhafazakâr kadınlar kavramını, kavramı tanımlamanın taşıdığı zorluklar karşısında ve feminist bir araştırma gerçekleştirmenin gerekleri doğrultusunda analitik bir strateji olarak tercih ediyoruz. Başka bir ifadeyle, araştırmacılar olarak muhafazakâr kadınlara bu sıfatı vermekten kaçınıyoruz; ancak bu kavramı kendi kimliklerini tarif etmek için nasıl tanımladıklarına odaklanarak çeşitli boyutlarıyla tartışıyoruz. Böylece, muhafazakâr olarak sabit konumlara yerleştirilen kadınların failliğini vurgulamak ve kadınların deneyimini öne çıkarmak istiyoruz. Yaşanan dönüşümü anlamak için, kadın deneyimleri oldukça önemli bir yere sahiptir; bu nedenle, çalışmanın odağında kadınların deneyimleri yer alır (Hirsh ve ark., 1995: 225; Scott, 2013). Muhafazakârlığ 1 gündelik hayat ve tüketimle ilişkili olarak ele almak, genişleyen muhafazakâr üst ve üst orta sınıfın hem cinsiyet kimliklerinde, hem de muhafazakâr kimlikte yarattığı dönüşümü anlamaya yönelik bir çaba olarak görülmelidir. 


\section{Yöntem}

Çalışmanın verileri feminist bir metodoloji ile gerçekleştirilen nitel bir saha çalışması ile toplanmıştır. Saha araştırması Gaziantep’te 2019 yılında, Mart ve Eylül aylarını kapsayan altı aylık bir süre içinde, çalışmaya katılan muhafazakâr kadınlarla gerçekleştirilen, onların gündelik yaşamlarına ve deneyimlerine odaklanan 14 birebir görüşme, 27 derinlemesine görüşme ile toplamda 14 kişiden oluşan iki farklı grupla yapılan iki odak grup görüşmesine dayanmaktadır. Görüşmelerde, önceden hazırlanmış bir soru kâğıdı yerine, planlanmış açımlayıcı (probing) konuları da içeren görüşme kılavuzu kullanıldı. Araştırmaya katılacak kişiler kartopu örneklem yöntemi ile belirlendi. Bu sayede üst-orta sınıftan muhafazakâr kadınların oluşturduğu belirli bir ilişkiler ağının bizzat araştırmaya katılanlar tarafından anlamlandırılması ve oluşturulması amaçlandı.

İlk katılımcıların kişisel bağlantıları ve aracı konumu, araştırmaya diğer katılımcıların dâhil olmasında olumlu bir etki yarattı. Tüm görüşmeler katılımcıların evinde gerçekleştirildi. Odak gruplardan biri yine katılımcılardan birinin evinde, diğeri ise kamuya açık bir mekânda, katılımcıların sıklıkla gittiği bir kafe/restoranda yapıldı. Bireysel görüşmeler ile odak grup görüşmeleri birbirinden farklı iki tür gözlemin yapılmasına olanak veren bağlamlar içinde gerçekleşti. Ervin Goffmann'ın (2014) sahne arkası ve sahne önü olarak ayırdığı iki tür performans, sırasıyla bireysel görüşmeler ve odak grup görüşmelerini tanımlayıcı nitelikler olarak araştırmaya katkı sağladı. Buna göre birebir görüşmelerde, katılımcıların kendi evlerinde kişisel deneyimleri hakkında daha açık, dolaysız konuştuğu, odak gruplarda ise kimliklerini sergiledikleri performatif bir bağlamın ortaya çıktığı daha belirgin olarak gözlemlendi. Başka bir ifadeyle, kadınlar arası etkinlikler olarak planlanan odak grup görüşmeleri, sınıfın sergilendiği ortamlar olarak araştırmacıya değerli bir gözlem firsatı yarattı.

Tüm birebir görüşmeler ve odak grup görüşmelerinde ses kaydı alındı ve daha sonra kayıtlar araştırmacı tarafindan yazıya aktarıldı. Görüşmelerin yazıya aktarılması sırasında her bir katılımcıya takma isimler verilerek katılımcıların gizliliği sağlanmaya çalışıldı. Görüşme kayıtları, görüşmelerden çıkarılan muhafazakâr kimlik, din, eğitim, kadınların çalışması, ev işi, turizm, umre ve hac ziyaretleri, toplantılar, mevlitler, düğünler, dekorasyon ve mobilya, israf ve etniklik gibi temalar çerçevesinde yorumlanarak analiz edildi (Creswell, 2017: 152-165). Çalışmanın şekillenmesinde hem aracı, hem de katılımcı olarak araştırmaya katılan tüm kadınların katkısı bulunmaktadır. Bunun yanı sıra, tez çalışmasını gerçekleştiren araştırmacının Gaziantep'te yaşaması, akrabalık ve tanışıklık bağları yoluyla yerel ile ilişkilendirilen ve yereldeki gündelik hayatı tanıyan biri olması görüşmeleri şekillendiren önemli bir başka unsurdur. Yerel ortaklıkların kültürel ortaklıklara, başka bir ifadeyle, birbirine tercüme edilebilir gündelik pratiklere dayanıyor olması önemli bir farklılık yaratmıştır. Her ne kadar alan araştırmasında güven konusu önceden belirlenmiş ve değişmez değilse de, bu ortaklık, katılımcılar ile araştırmacı arasındaki güven ilişkisinin kurulmasına katkıda bulunmuştur. 


\section{Türkiye'de muhafazakârlık: Siyasal ve toplumsal anlamı ve dönüşümü}

Türkiye'de muhafazak ârlığın tarihsel anlatısının siyasal ve toplumsal bir deneyim olarak modernleşmeye dayandığını söyleyebiliriz. 19. Yüzyılın ilk yarısında Tanzimat Fermanı ile başlayan reformist Osmanlı modernleşmesi Cumhuriyet'in ilanıyla birlikte siyasal ve toplumsal anlamda modernleşme deneyimini ileri taşıyan bir dönüşüm yaratmıştır. Modernleşmeye yönelik bir eleştiri olarak muhafazakârlık bu tarihsel koşullarda şekillenmiştir. Modernleşmenin tarihsel süreci, siyasal ve toplumsal kırılmaların ve sürekliliklerin anlaşılmasında önemlidir. Türk siyasal ve toplumsal kültüründe, muhafazakârlığın din ve gelenekler temelinde modernleşmenin karşıtı olarak kavramsallaştırıldığı, bu anlamda özellikle Cumhuriyetle birlikte gericilik olarak tanımlandığı ve rejime veya reformlara yönelik tehdit olarak görüldüğü de belirtilmelidir (Zürcher, 2013: 50). Bu nedenle 1950 öncesine kadar, muhafazakârlık bir sıfattan ziyade, bir isim olarak kullanılmış, siyasal olarak rejim karşııtı olmak olarak anlaşılmıştır (Bora, 1998: 73). Çok partili hayata geçiş ve özellikle de Demokrat Parti'nin iktidara gelmesiyle bu durum değişmiş ve muhafazakârlık siyasal ve kamusal alana çıkmıştır. Bu dönemde modernleşmenin değil, muhafazakârlığın siyasal iktidar açısından araçsallaştırıldığını söylemek olanaklıdır. Moderne yönelik tavır, sınıfsal yer değiştirme ile yakından ilişkilidir. Dönemin siyasal elitlerinin toplumsal kökeni Cumhuriyetin kurucu elitlerinden farklı olarak mülk sahibi orta sınıf ve yerel eşraftan oluşmaktadır (Yelsalı Parmaksız, 2017: 94, 119). 1950'lerden 1980'lere kadar olan tarihsel dönemde, İslami referansların yanında taşralılığa dayanan "bir tür püritanizm," içki yasağ1, büyüğe hürmet, tesettür ve bireylerin cinsel pratikleri üzerindeki denetim gibi yaşamın çeşitli alanlarını etkilemiştir (Mardin, 2008: 32).

1980'lerden itibaren dünyada yükselen yeni sağ ve yeni muhafazakâr siyaset, Türkiye'de de 24 Ocak Kararlarının uygulandığ 12 Eylül 1980 Darbesi'ni izleyen dönemde milliyetçi muhafazakâr temsilin dar kalıplarını kırarak kendi özerk alanını inşa etmesine yol açmıştır (Taşkın, 2017; Bora, 2017: 404). Ekonomide dışa açılma ve yeniden yapılanma sonucunda sosyo-kültürel anlamda muhafazakâr olan yeni bir müteşebbis sınıf ortaya çıkmıştır. Tüketim, başta sınıfsal kimlik olmak üzere kimliğin toplumsal olarak oluşumunda önem kazanmıştır. Finans ve sermaye temelli bir birikimi gerçekleştiren sınıflar açısından tüketim, ayırıcı bir pratik haline gelmiştir. Yerelde ise Anadolu Kaplanları olarak adlandırılan büyük sermaye birikimini gerçekleştiren muhafazakâr grupların ortaya çıkması sınıfsal olduğu kadar, muhafazakârlık açısından da dönüştürücü bir dinamik ortaya çıkarmıştır.

1990 yılında bu grupların temsilcisi olarak Müstakil Sanayici ve İşadamları Derneği (MÜSİAD)'nin kurulması bencil ve bireyci olarak düşünülen Homo-Economicus kavramının alternatifi olarak (Hoşgör, 2013: 229) toplumun ortak paydasını gözeten, manevi değerlere sahip çıkan ve ahlaki bir çerçevede kapitalizmi onaylayan Homo-İslamicus kavramını öne çıkarmıştır (Yankaya, 2014, 210). Öte yandan, bu dönemde enformel ilişki ağları olan tarikatların ve cemaatlerin önünün açılması (Hoşgör, 2013: 221), dini örgütlenmelerin, ilişkilerin ve (b)ağların ekonomik açıdan 
sermaye üreten bir araç haline gelmesine (Cengiz, 2013; 27), başka bir ifadeyle dinin bir ilişki sermayesine, yani sosyal sermayeye dönüşmesine yol açmıştır.

Yanı sıra, 1980'lerden itibaren Müslüman kadınlar toplumsal ve siyasal olarak artan bir görünürlük kazanmışlardır (Arat, 2016). 1968 yılında başörtülü bir öğrencinin okuldan atılmasıyla başlayan protestolar ve boykotlar başörtülü kadınların siyasal hareketliliği açısından bir dönüm noktası olmuştur. Din dolayımıyla muhafazakârlıkla ilişkilendirilen başörtüsünü modernleşmenin ön koşullarından biri olarak görülen eğitim kurumları gibi kamusal ortamlarda kullanma talebini dile getiren kadınların konumu, modernleşme perspektifinden bakıldığında bir paradoks olarak görülmüştür (Göle, 2016: 132). Ayrıca, bu kadınların varlığının ve taleplerinin onların görünürlüğ̈̈nü artırdığını, bu nedenle hem Kemalist seçkinlerce oluşturulan homojen laik kamusal alanı, hem de kadını özel alanda tanımlayan geleneksel İslami anlayışı sorgulamaya açtı̆̆1 söylenebilir (Çayır, 2017: 42). Başörtüsü mücadelesi içinden gelen kadınlar 1980'li yılların ortalarından itibaren Mektup, Kadın ve Aile gibi dergiler yayınlamaya başlamış, tüketimi ve modayı eleştiren, Müslüman kadının nasıl olması gerektiğini, annelik ve aile için rolleri tartışan yazılar yazmışlardır (Acar, 1990, Arat, 1990).Yelsalı Parmaksız, 2017: 196). Aynı dönemde dindar/İslamcı kadınların, derneklerde ve çeşitli platformların çatısı altında örgütlü bir şekilde yer aldıkları görülür (Aktaş, 2005: 833, Köse, 2014: 205, Yılmaz, 2015: 21-23, Çayır, 2017: 41).

1990’lar Müslüman kadınların kurumsal siyasetle eklemlendiği bir dönem olmuştur. Bir sosyal hizmet şebekesi olarak çalışan dönemin siyasal İslam çizgisinde yer alan partilerin faaliyetlerinin örgütlenmesinde kadınların katkısı büyüktür. Partili kadınlar, erkek partililerin mahalle yapısı ve yaşam tarzı dolayısıyla giremedikleri evlere ziyaretler yapmışlar, kadınlar arası iletişim ve etkileşim ağlarına dâhil olmuşlar, bu ziyaretleri sırasında edindikleri bilgiye dayanarak ihtiyaçları belirlemişler ve yardım faaliyetlerini buna göre planlayarak gerçekleştirmişlerdir. Bu ev ziyaretlerinin önemli bileşenlerinden biri dindir. Bir yandan ziyaretler ve yardımlar yapılırken, bir yandan da evlerde dini sohbetler gerçekleştirilmiştir (Tuğal, 2011: 74-75). Evin bu şekilde, yani örgütlenme, eğitim, parti faaliyetleri gibi amaçlarla kullanılması evin özel alan algısını ve gündelik pratikler içindeki yerini dönüştürmüştür (Y1lmaz, 2015: 229, 236).

2000'li yılların başına kadar birbirinin devamı kabul edilebilecek siyasal İslami çizgiyi benimseyen partiler Anayasaya aykırılık iddiasıyla kapatılmıştır. 14 Ağustos 2001 tarihinde kapatılan partilerle birlikte merkez sağın önemli bileşenlerini içeren Adalet ve Kalkınma Partisi (AKP) kurulmuştur. 2002 yılında yapılan ilk seçimde AKP sandıktan birinci parti olarak çıkmıştır. AKP'nin tanımladığı muhafazakâr demokrat çizgi (Akdoğan, 2004) serbest piyasa ve liberal haklar ve özgürlükler konusunda olumlu bir tutum takınan neo-liberal, yeni-muhafazakâr bir güzergâhı temsil eder. Bu çerçevede, AKP'nin ilk yıllarında, başörtüsü de dâhil olmak üzere birçok konunun evrensel kişisel hak ve özgürlükler ile ilişkilendirilerek ele alındığı görülebilir. Öte yandan, aileyi ve kadının aile içindeki konumunu merkeze koyan, feminizmi ve feministleri uzak tutarak reddeden bir siyasetin bir arada sürdürüldüğünü 
belirtmek gerekir. AKP dönemini özellikle kadınlara yönelik söylem ve politikaların dönüşümü açısından dört döneme ayırırsak, demokratik ve liberal tonun 2002-2007, 2007-2011 ve 2011-2015, 2015'ten bugüne ataerkil, muhafazakâr ve neo-liberal bir çizgiye evrildiği söylenebilir (Yelsalı Parmaksız, 2017: 220). Kamuda başörtüsünü serbest bırakan 8 Ekim 2013 tarihli düzenlemenin, siyasal söylemde muhafazakâr alanla sınırlandırılmış bir ahlak meselesinin çözüme kavuşturulması olarak sunulması (Coşar ve Yeğenoğlu, 2013: 176) bunun göstergesidir.

Genel bir saptama olarak modernleşme sürecinde kadınların, medeniyete katılmanın ölçüsü olarak görüldüğü, hem Osmanlı Devleti, hem de Cumhuriyet'in modernleşme söyleminin karşısında konumlanan "öteki" ile farkı kurmada hayati bir yere sahip olduğu görülür. Muhafazakâr toplumsal gruplar açısından da kadınlar benzer bir konumdadır. Bunun çok çeşitli nedenleri olmakla birlikte, özellikle de Türkiye deneyiminde muhafazakârlı̆̆ın, daha çok din ile ilişkilendirilmesinin, dinin de kültürel bir anlam repertuvarı olarak kadınları içerecek şekilde kurulmasının etkisi vardır (Köse, 2014; Yılmaz, 2015). Bunun sonuçlarından biri 2013'te kamuda başörtüsüne serbestlik getiren düzenlemenin başörtüsünün kamusal ve özel tüm alanlarda görünürlüğünü artırmış olmasına karşın, başörtüsü meselesinin kadınlarla ilgili olarak siyasal söylemin sembolik bir unsuru olarak ortadan kalkmamasıdır. Dolayısıyla, muhafazakârlık kadınlara ilişkin kimlik kurucu bir temsil ilişkisi kurması nedeniyle kadınların deneyimini anlamak açısından önemli sınırlıkların içerir. Ayrıca, bugünden geriye bakıldığında, başörtüsü mücadelesinin önceki kuşağın siyasal ve sosyal talebi olması, yani bu mücadelenin yeni kuşak açısından güncelliğini yitirmesi muhafazakâr kimlikteki dönüşümler açısından güncel başka dönüşümlerin hesaba katılmasinı zorunlu k1lar.

\section{Gaziantep yerelinde taşra muhafazakârlığı, İslami muhafazakârlık ve ka- dınlar}

2000'lerden itibaren gerek siyasal gerekse gündelik hayatta gözlemlenen değişimlerin en belirgin olarak yaşandığ 1 yerlerden biri Türkiye'nin Güneydoğu Anadolu bölgesinin tarihsel olarak önemli ticaret ve sanayi merkezlerinden biri olan Gaziantep'tir. Tarihi İpek Yolu üzerinde bulunan Gaziantep, hem yeni ekonomi politikaları, hem de Güneydoğu Anadolu Bölgesi'nde yaşanan güvenlik sorunları ve çatışmalar nedeniyle yoğun göç alan illerden biri olmasıyla nüfus bakımından Güneydoğu Anadolu'nun en büyük ili haline gelmiştir. Kentin ekonomik cazibesi yalnızca iş bulmak için gelen yoksul kesimleri değil, aynı zamanda iş kurmayı hedefleyen sermaye sahiplerini de etkilemektedir. İkinci grupta daha doğudaki illerden Gaziantep'e gelip yerleşen Kürtler de bulunmaktadır. Bu makale kapsamında sınırlı olarak ele alınsa da bu makalenin dayandığı araştırmanın verilerinden yola çıkarak, Gaziantep'te etnikliğin yaşam tarzları, kültürel tercihler ve beğeniler üzerinde etkisi olan önemli bir unsur olduğu anlaşılmıştır. 
Karadağ (2010)'a göre 1960'lara kadar, kentin sosyal ve kültürel hayatında hâkim ve etkili bir konumda olan yerel eşraftan aileler, kentin ekonomisinde tarımın önemli olduğu dönemde, tarıma yönelik yatırımlar yoluyla sınıfsal olarak farklılaşmış, yerelde sahip oldukları sınıfsal konumu ulusal düzeyde milletvekilliği gibi pozisyonlarla statü konumlarına dönüştürmüşlerdir. Yerel eşraf kent yaşamında batılı bir yaşam tarzını temsil etmiş, batılılaşma projesinin gündelik yaşama uyarlanmasında öncü olmuştur. Eşraf ailelerinin sınıfsal ayrımlarının oluşumunda kadınların ev içinde ve ev dişında yürüttükleri etkinliklerin önemli bir yere sahip olduğu söylenebilir. Tedrici bir ekonomik, siyasal ve sosyal değişim ve dönüşümün sonucu olarak günümüzde bu merkezi konum, sanayici işadamlarına ve ailelerine geçmiştir (Ayata, 2004: 560). Bu yeni sanayici sınıfın ister yerleşik, isterse göçle gelmiş olsun, ekonomik faaliyetlerinin yanı sıra dindar muhafazakâr değerler konusunda kendi içinde ortaklaştıkları söylenebilir (Uysal, 2011: 448). Bugün Gaziantep'in toplumsal ve kültürel yaşamında dikkati en fazla çeken şey, tüketimin gündelik hayata etkisinin artmasıdır (Karadağ, 2011: 407). Süpermarketlerin ve alışveriş merkezlerinin sayısının hızla artması, bir taraftan tüketimi, diğer taraftan ise küresel tüketim kültürü ile ilişkilenme biçimini dönüştürmüştür. Ancak yine bu dönemde, özellikle de 1990'l1 yıllardan itibaren, kentin, toplumsal ve kültürel hayatında dinin etkisinin artması tüketim alanında da kendisini göstermiş, İslami olarak nitelendirilen yaşam tarzı ile muhafazakâr taşra kültürü birbirine eklenerek yeni tüketim pratikleri ile uyumlu biçimler almıştır.

Ekonomik açıdan dinamik bir yapıda olmasına karşın, sosyal ve beşeri kalkınma göstergelerinin önemli bir kısmının halen Türkiye ortalamasının altında olması, mülki idare sisteminde Büyükşehir Belediyesi olan Gaziantep'i taşra olarak tanımlamanın altında yatan nedendir (Geniş ve Adaş, 2011: 295).

Taşrada kadının yersiz yurtsuzluğundan söz eden Çur (2018: 123), eğitimli ve toplumsal olarak uygun görülen öğretmenlik, memurluk gibi bir mesleğe sahip kadınlar dışında kadınların ev kadını olmak dışında başka bir seçeneklerinin bulunmadığını ifade eder. Aynı durum Gaziantep'te yaşayan kadınlar açısından da geçerlidir. Gündüz Hoşgör (2011: 504), Türkiye'de eğitim düzeyi ile istihdam arasında pozitif bir ilişki olmasına rağmen, Gaziantep'te, üniversite veya yüksekokul mezunu kadınlar arasında istihdama katılımın düşük olmasının geleneksel aile yapısının etkisi ve kadının yerinin "evi olduğu” yaklaşımının varlığı ile ilgili olduğunu belirtir. Ayrıca, ildeki KOBİ sayısının yüksekliğine rağmen kadın girişimci sayısının oldukça az olduğu görülür. Eğitim düzeyi düşük kadınların ise, parça başına iş/üretim veya fistık kırma, dantel ve nakış gibi evden sürdürebildikleri işlerle meşgul oldukları, başka bir ifadeyle düşük gelirli ve düzensiz olan enformel istihdama dâhil oldukları görülür.

Sermayenin farklı sınıflar arasında yer değiştirmesi, siyasal ve toplumsal dönüşümlerden yoğun olarak etkilenmesi, göç ve küresel etkiler altında dönüşen bir kent olması nedeniyle Gaziantep, muhafazakârlığı ve muhafazakâr kimliği anlamak açısından elverişli bir bağlam sunmaktadır. Muhafazakârlığın farklı tarihsel dönemler- 
de farklı anlamlara sahip olması gibi, farklı toplumsal bağlamlar içinde, özel olarak da farklı sınıflar açısından aynı şeyi ifade etmediği (Gökgöz, 2016: 125) ileri sürülebilir. Buradan hareketle muhafazakâr kimliklerin kadınlar için anlamını sorgulamak toplumsal cinsiyetle birlikte kesişimsellik içinde bulunan sınıf ve etnik kimlik gibi etmenlerin hesaba katılmasını gerektirir.

\section{Muhafazakârlığı tanımlamak: "Bizimki dediğim gibi, daha modern. Ka- palılığı modernleştirmek"}

Yukarıda anlatılan nedenlerle muhafazakârlık sabit bir kimlik olarak ele alınamaz. Buradan hareketle araştırmaya katılan kadınlar muhafazakâr olarak konumlandırılmış olsalar da, onların muhafazakârlığı ve kendilerini nasıl tanımladıkları bu araştırmanın hareket noktasını oluşturmaktadır. Katılımcıların çoğu muhafazakârlığı dinle ilişkilendiriyor olsa da kendilerini çeşitli nedenlerle muhafazakâr olarak nitelendirmedi. 50'li yaşlarında, lise ikinci sınıfa kadar eğitim almış bir ev kadını olan Sevim, muhafazakâr olmadığını söylemekle birlikte, kendisine göre kimin muhafazakâr olduğunu şöyle anlattı:

"Ben mesela namazımı kılarım, orucumu tutarım, yani dini görevlerimi yerine getirmeye çalışırım. Çok kapalı değilim. Zamana uygunum. Muhafazakâr dediğin baya bir baskıcıdır, bizde yok, rahat[1z] yani. Çocuğumuzu filan rahat bırakmışızdır. Dini şeylerimi yaparım ama o ayrı bir şey. Muhafazakâr dediğin daha dindardır."

Farklı yaşlarda kızları olan Sevim, önceki yıllarda büyük kız çocuğunu üniversite eğitimi için şehir dışına göndermediğini, maddi olanakları elverişli olmasına rağmen, çevreden çekindikleri için eve özel ders için erkek öğretmen dahi çağırmadıklarını söyledi. Bu nedenle, geçmişte tarif ettiği muhafazakâr profiline kendisinin de uyduğunu, ancak küçük kızlarının evde özel ders de aldığını, hatta şu an üniversite eğitimi için şehir dışında olduğunu belirterek değiştiklerini anlattı. Sevim'e göre zamana uyamayanlar ve eski yaşam tarzlarını sürdürenler muhafazakârdı ve muhafazakâr kalmak kültürel sermaye eksikliğinin göstergelerinden biriydi. Bu haliyle, muhafazakârlık, yalnızca ekonomik sermaye ile bağlantılı olmayan sınıfsal bir fark1 gösteriyordu.

Muhafazakârlığın tanımlanması açısından dış görünüş ve giyim kuşam da katılımcılar açısından belirleyici bir gösterge olarak tanımlandı. 50'li yaşlarında, lise mezunu, bir ev kadını olan Gül, muhafazakârları "çok kapalı, çok daha, böyle at gözlüğü takan" kişiler olarak gördüğünü ve kendisinin hem bu profile hem de muhafazakârlığın tam karşısında konumlandırdığı ve rahat/açık olarak tanımladığı diğer profile pek uygun olmadığını, kendisini daha çok ortada gördüğünü ifade etti. Gül muhafazakârları, "bizden daha kapalı olanlar var, hiç pantolon giymeyenler var, pardösü ile gezenler var, onlar bana göre daha muhafazakârlar" şeklinde tarif etmekteydi. 
Katılımcılar arasında, muhafazakârlık ile giyim tarzı arasında ilişki kuranların sayıs1 az değildi; ancak bunlar, Gül'ün muhafazakâr olarak değerlendirdiği kişilere atfettiği olumsuz özellikler konusunda Gül ile ayrışıyorlardı. Onlar için, muhafazakârlık ve onunla ilişkilendirilen giyim tarzı, emredildiği şekilde, dini anlayarak veya Kuran-1 Kerim'i temel alarak yaşamak anlamına geliyordu. Bu nedenle, bu kadınlar için, muhafazakârlık ve onunla ilişkilendirilen giyim tarzı kaçınılması gereken değil, erişilmesi ya da ulaşılması gereken bir şeydi. 50'li yaşlarında, ilkokul mezunu ev kadını Mukaddes'in muhafazakâr olmadığını söyledikten sonra, "Rabbim nasip etsin tam anlamıyla kapanmayı" şeklindeki dileğini de bununla ilişkilendirebiliriz. Verilen yanıtlar tesettürün doğrudan muhafazakârlıkla ilişkilendirilmesinin artık mümkün olmadığını düşündürmektedir. Katılımcıların muhafazakârlıkla ilişkilendirdikleri giyim tarzının amacı, bedeni silikleştirmek ve sınıfsal ayrımları yok etmekken, kendileri, tesettür modasını takip ettikleri için, bu idealden uzaklaştıklarını düşünüyorlardı. Üst orta sınıfın oturduğu bir semtte muhafazakâr kadınlara yönelik butik işleten 30'lu yaşlarının sonlarında, lise mezunu bir ev kadını olan Dilek'in, başörtüsü ve moda arasındaki ilişkinin muhafazakârlık açısından doğurduğu sonuçlara ilişkin yorumu örnek verilebilir:

"Şu an giyim tarzımı, başörtümü, muhafazakâr olarak görmüyorum açıkçası, yani keşke yapabilsem, eşarbımı biraz daha düzgün bağlasam. Bizimki dediğim gibi, daha modern. Kapalılığı modernleştirmek.”

Yukarıda belirtildiği gibi başörtüsünün gündelik biçimlerinin zaman içinde değişmesinde modanın önemli bir payı vardır. Navaro Yaşın'ın (2017) tesettür giyim sektöründe öncü firmalardan biri ile yaptığı görüşmede, firma sahibi, sektöre getirdikleri yenilikleri anlatırken yeni tarz giysilerin "kapanmaya" ilgiyi arttırdığını da dile getirmiştir. Bu yönüyle dine hizmet misyonu ile birlikte sunulan tesettür modasındaki gelişmenin ve çeşitlenmenin dini kimliğin sürekli ve hatta seçici bir tarzda inşa edilmesine katkıda bulunduğu söylenebilir. Öte yandan, modayı takip etmenin, belirli bir parasal sermayeyi gerektirdiği de açıktır. Bu nedenle, başörtüsünün/tesettürün sınıfsal ayrımları gizlediği ve/veya gizlemeye yönelik işlevi ortadan kalkmıştır. Bunun da ötesinde başörtüsü sınıfsal ayrımları vurgulamanın bir aracı haline gelebilmektedir. 40'lı yaşlarında, lise mezunu, ev kadını Sevgi'nin, kuzenleri hakkında anlattıkları bunun göstergesidir:
"Mesela benim kuzenlerim kapandılar üniversiteye giderken. Arkadaşları vardı, arkadaşları da çok zengin bir ailenin kızı, kapalıydı. O kıza özendiler, işte şal kapatıyor, güneş gözlüğü tepesinde, altında lüks araba. Kuzenleri- min ikisi de kapandı. Ama bu kızlar ciddi anlamda şık giyiniyordu [...]"

Benzer şekilde, başörtüsü dinsel anlamının ötesine geçerek belirli bir kültürel sermaye unsuruna dönüşerek sınıfın göstergesi haline gelebilmektedir. Sevgi'nin tanıdıklarından, dindar olmayan ve dini pratiklerini yerine getirmeyen biri, oldukça "muhafazakar ama çok zengin bir çevresi" olduğu için, onlar gibi olmaya çalışmak amacıyla kabul gören giyim kodu olan başörtüsü kullanıyordu. 
Ayrıca, geleneksel başörtüsü (eşarp) ile farkı göstermek açısından da moda belirleyici olmuştur. Cumhuriyet'in ilk yıllarında kırsal hayat tarzıyla özdeşleştirilerek Türkiye'de kültürün folklorik bir yönü olarak romantize edilen geleneksel başörtüsü, 1950'lerde başlayan ve giderek artan köyden kente göçle birlikte, sınıf ayrımının belirleyenlerinden birine dönüşmüş ve giderek kente göç etmiş kırsal kökenden-alt sınıf kadınlarının sembolü haline gelmiştir (Acar ve Altunok, 2017: 86). Dindar/ muhafazakar bir kimliğin ayırıcı unsuru olarak simgeleşen başörtüsü ise kültürel bir tercih olarak bir farkın göstereni haline gelmiş, İslami öze atfedilen anlamlarla birlikte dindarlı̆̆ dişilleştirmiştir (Köse, 2014: 108). Ancak araştırmaya katılanlar bu ayrımın Gaziantep'te başka bir biçimde kurulduğuna işaret etmiştir. Çene altından eşarp bağlama şeklindeki geleneksel başörtüsü ile "yeni bağlama biçimi" arasındaki fark, yerli ve köylü Antepliler arasında, esasen eski ve yeni burjuva sınıfı arasındaki farka karşıllk gelmektedir. Annesi Gaziantep'in yerlisi olan Gül'ün, yerlilerle ilgili ifadeleri de bu durumu gösterir niteliktedir: "Yerlisi hiç muhafazakâr değil. Daha Cumhuriyetçidir, her zaman Cumhuriyet zihniyetli olmuştur onlar." Dolayısıyla bu araştırmanın verileri bağlamında geleneksel başörtüsü tek başına dini bir referansın ötesinde, Cumhuriyetçi modernlikle bağlantılı taşralı bir muhafazakârllğı içerir.

\section{Gösteriş̧̧i tüketim ve kadınlar arası karşılaşmalar: "Ben şu an dört kişi- lik bir aileyim, dört tane araba var kapıda"}

Gaziantep'te eski ve yeni sınıf arasındaki ayrımları kuran çeşitli sermaye türleri bulunmaktadır. Bunlardan ekonomik sermaye, eski zengin-yeni zengin arasındaki farkta belirginleşir.Burada eski zenginler olarak tanımlanan yerli Antepliler tutumlu, birikim yapan ve kazançlarını tüketmek yerine yatırıma aktaran kişiler olarak görülürken, yeni zenginler kazanç firsatlarından yararlanmayı bilen, girişimci ve ekonomik olarak başarı kazanmış özellikleriyle öne çıkarılmaktadır. Kültürel sermaye açısından gösteriş düşkünlüğü, özentilik, yetersizlik veya bilgisizlik gibi sıkça başvurulan nitelemeler devreye girmektedir. Üstelik kültürel sermaye ekonomik sermaye açısından belirsiz görünen yeni zenginler arasındaki ikinci düzeyde sınıfsal bir ayrımı belirginleştirmek açısından da kullanılmaktadır. Etnik farklılığa dayanan bu ayrım, Gaziantep'e göçle gelen "doğulu” yeni zenginlerin yerelde sınıfsal merdivenin en altında görüldüğünü ortaya koymaktadır. Gaziantep'in yerel bağlamında şehre göçle gelen Kürtler ve Araplar doğulu olarak tanımlanmaktadır.

Eski ve yeni üst orta sınıf arasındaki farkların kurulmasında ve sürdürülmesinde tüketim pratiklerinin belirleyici bir işlevi bulunmaktadır. Yeni muhafazakârlar açısından tüketim lüks ve aşırı da olsa; israf olarak değerlendirilse de, onaylanan bir davranıştır. Örneğin Şükran, israfın dinen yasak olduğunu ifade ediyordu. Buna karşın, kendini muhafazakâr olarak görenlerin aşırı ve lüks tüketimi ekonomik refah temelinde meşrulaştırdıklarını anlatıyordu: "Vardır alıyorum diyordur. Param çok, kazanıyorum, emek veriyorum, istediğim lüksü de yaşarım diyordur." Bunun da ötesinde, tüketim özgürlüğünün bireysel özgürlükle eşdeğer tutulduğu anlaş1lmakta- 
dır. Modernliğe katılmanın bir yolu olarak tüketim bu şekilde meşrulaştırılmaktadır. Kendisiyle faklı siyasal görüşlere sahip yakın bir arkadaşını eleştiren Sevgi'nin anlattıkları lüks tüketimin meşrulaştırıcı işlevini örnekler:

"[Ona diyorum ki] sen 20 sene önce kiracıydın, benimle birlikte otobüse biniyordun, bak şu an kocanın işi var, senin cipin var, kocanın Mercedes'i var. Ben şu an dört kişilik bir aileyim, dört tane araba var kapıda. Hepimiz kalkındık, yani ülke gelişti. Ben muhafazakârım, zengin oldum, sen [de] yerinde saymadın."

$\mathrm{Bu}$ örneği, imajların ve tüketim mallarının çoğulluğunun, yani farklı tüketim ürünleri arasından seçim yapabilme özgürlügünün demokratik çoğulculuk olarak anlaşıldığı 1980 sonrasında neo-liberal yeni sağın genel çerçevesi (Özkazanç, 1998'den akt. Yelsalı Parmaksız, 2017: 174) içinden okumak mümkündür.

Gösterişçi tüketimin sergilendiği en önemli alan kadınlar arası kamusallıklar olarak ortaya çıkmaktadır. Burada geleneksel olarak evlerde veya evlerin uzantıs1 mekanlarda gerçekleştirilen ya da geleneksel cinsiyete dayalı mekansal ayrımı karma mekanlarda yeniden inşa eden ve/veya inşa etme iddiasında olan alanlarda gerçekleştirilen "toplantılar" ve mevlitler ele alınacaktır.

\subsection{Toplantılar}

Katılımcılar arasında, daha önceleri kabul günü veya gün, şu an ise, "toplantı" olarak adlandırılan etkinliğin en yaygın sosyalleşme biçimlerinden biri olduğu söylenebilir. Toplantı, altın gününün muadili olarak düşünülebilebilir, ancak bu toplantılarda altının yerini para almıştır. Kabul günü ya da bu araştırmada katılımcılar tarafından kullanılan adıyla toplantı, geleneksel olarak kasaba ve kentlerde yaşayan orta ve üst orta sınıftan kadınların belli aralıklarla, evlerde toplanarak birlikte vakit geçirdikleri, belirli bir sırayla dönüşümlü olarak farklı evlerde düzenlenen, düzenlendiği evde ev sahibinin hazırladığ ağırlarken görgü ve becerisini sergilediği oldukça rekabetçi nitelikteki etkinliklerdir (Benedict, 1974: 28-29; Tapper, 2007: 410).

Katılımcılardan Sevim bu etkinliğin isminin zaman içinde değişmesini şöyle açıklar: "Çok önceleri kabul denirdi, sonra gün dediler, şimdi de toplantı." Bu, basitçe bir isim değişikliğinden daha derinde anlamlar içermektedir. Nevin de, Selda da toplantı kelimesini kabul veya gün kelimesine göre daha "kibar" bulduklarını ifade ettiler. Nevin'e göre "kabul" daha "avratsı" bir kelimeydi. "Avratsı" kelimesinin yerel kullanımdaki anlamı kadınsı demekti; öte yandan katılımcılarla bu kelimenin anlamı üzerine konuşunca genel olarak daha ileri yaştaki kadınlara ve sınıfsal olarak alt sinıftan olmaya dair kısacası "eskiliğe ve avamlığa" dair göndermeler içerdiği anlaşı1ıyordu. Öte yandan Selda'nın vurguladığı gibi "şimdi [...] sanki kadınlar iş yapıyormuş gibi, o anlamda toplantı" demek tercih ediliyordu. Bu araştırmanın katılımcıları çoğunlukla ev kadınlarından oluşmaktaydı; ama eskiden günlere, şimdiyse 
toplantılara katılıyor olmak, başka bir ifadeyle bu etkinliği toplantı olarak nitelemek, kabul gününü, başta kendileri, daha sonra ise başka kadınlar ile diğer herkesin gözünde değerli kılmanın bir yolu haline geliyordu.

Bu isim değișikliğinin, davranış değişikliğini de beraberinde getirdiği söylenebilir. Eskiden kabul günlerinin bir parçası olan "oynama"nın giderek ortadan kalktığı gözlenmektedir. Katılımcılardan Gönül bu değişimi şöyle aktarmaktaydı:

"Eskiden bir de şu olayımız vardı, giderdik çalar oynardık yemekten sonra. Şimdi o yok mesela, millet modernleşti.O biraz banal oldu. Eskiden yemek, çay ve bir tur oynama. Ama şimdi o da neymiş diyorlar, biraz daha sosyetik oldular. Eskiye nazaran sosyete oldu millet."

Bunu destekler şekilde, daha genç kuşaktan Gönül'ün ve Sevim'in kızları, kendilerinin de toplantıları olduğunu, ancak toplantıda oynamayı çok saçma ve itici bulduklarını söylediler.

Kadınların toplantıya giderken çok özenli davrandıklarını, özel ve önemli bir davete veya bir iş yemeğine katılacak gibi hazırlandıklarını söylemek gerekir. Sevim'in ifadeleri bu özeni anlatır: "O gün kendini çok özel hissedersin, masalar dizilir, en güzel yemekler yapılır. Giyinirsin, kuaförlere gidersin. Süslenirsin. Havalı havalı, topuklu ayakkabılarla..." Dilek' in toplantılarla ilgili söyledikleri, toplantılara gösterilen özenin, sınıf ile ilişkilendirilen yoğun bir gözlem ve toplumsal denetim ile ilgili olabileceğini gösterir : “...Şu an ticaret. Aslında bu toplantının adı değişmeli. Ekonomiyi canlandırma toplantısı olmalı. Şu filan yerde, şunu aldım, ay çok güzel bir ürün var. Ay saçımı şuraya boyattım. Takını nereden aldın, saatini nereden aldın?" Görüldüğü gibi toplantılara katılan kadınlar belirli bir beğeni hiyerarşisine tabi olurlar. Beğeni hiyerarşisi, zenginlik veya varlık ile ilişkilendirilen diğer hiyerarşiler kadar önemli ve belirleyici olabilir. Kadınların, aile içinde, zevki kuran ve beğenileri inşa eden ve aynı zamanda bunları sergileyebilen kişiler olarak görülmesi ve bunların da kadının ve hatta ailenin sınıfı ile ilişkilendirilmesi, kadınların karşılaştıkları toplantı gibi alanlarda sınıfsal kaygıları gün yüzüne çıkarır. Sınıfını sürdürmek, göstermek veya sınıfsal kaygıları gidermek açısından oldukça önemli ve işlevsel olan bir etkinlikte, kültürel sermaye eksikliği gibi, sınıf ile doğrudan ilişkili bir konuda yetersiz veya eksik olmanın veya öyle hissetmenin hiç istenmeyeceği açıktır. Bunun yanı sıra, toplantıların, çeşitli sınıfların, özellikle de üst orta sınıf kadınların tanışabildiği veya etkileşime girdiği bir etkinlik olduğu da hesaba katılmalıdır. Bu yönüyle ekonomik sermayenin kültürel sermayeye, onun da sosyal sermayeye dönüştüğü s1nıfsal ayrımların bu toplantılarda kurulduğu ve sürdürüldüğü düşünülebilir.

Toplantılar ev sahibinin evini, mobilyalarını, eşyalalarını, zevkini sergilemesi için de firsattır. Dilek, bu niyete uygun olarak toplantıların ilk turunun genellikle evlerde yapıldığını, ancak ikinci tur olursa kafe gibi mekanların tercih edildiğini ifade etti. Suna da benzer şekilde "Antika yemek takımları alınıyor, her toplantıda farklı şeyler çıkıyor" diyerek yalnızca ekonomik sermayenin değil, kültürel sermayenin 
de toplantılarda sergilendiğini anlatıyordu. Bu durumun ikramların sayısına, çeşitliliğine ve de aynı zamanda sunum biçimine de yansıdığı anlatıldı. Buna göre 15-20 çeşit yiyecek ikramı yapılan toplantılarda ikramların çeşit sayısı kadar sunuluş biçimindeki özen, stil ve tasarım da ev sahibinin sınıfsal hiyerarşideki yerini etkiliyordu.

\subsection{Mevlitler}

Görüşmeler sırasında, geçmiş yıllarda sohbet tarzı veya çeşitli sivil toplum kuruluşlarının düzenlediği etkinliklerin, kadınlar açısından dini sosyalleşmenin yaygın biçimleri arasında yer aldığı, ancak 15 Temmuz darbe girişimi sonrasında, çeşitli kaygılarla bu etkinliklere katılım oranında düşüş yaşandığ 1 ifade edildi. Öte yandan, dini sosyalleşme aracı olarak mevlitlerin oldukça popüler bir etkinlik olduğu gözlendi. Bilindiği gibi Mevlit, Sünni Müslümanlar tarafından kandil gibi dini günlerde ve/veya kişisel ve toplumsal olarak önem verilen evlilik, sünnet, doğum, ölüm gibi belirli olaylarla ilişkili günler vesilesiyle gerçekleştirilen, konuklara ikramların sunulduğu, Süleyman Çelebi'nin aynı adlı manzum eserinin makam eşliğinde seslendirildiği, ilahilerin ve duaların okunduğu bir etkinliktir. Mevlit, peygamberin hayatına ilişkin bilgilerin verilmesi, dualar ve Kuran-1 Kerim'in okunması gibi, dinî yönünün yanı sıra, topluluğu, bir araya getirerek, onun kimliğini yeniden üretmek veya ona katkı sunmak gibi, çok çeşitli işlevleri olan bir etkinlik olarak değerlendirilebilir. Kabul gününden farklı olarak mevlitler, sosyal ve sınıfsal ayrımların daha az gözetildiği, mevlitin yapılma nedenine (doğum, ölüm, sünnet gibi) bağlı olarak, farklı sosyal tabakadan kadınların dinî motivasyonlarla düzenledikleri ya da davet edildikleri etkinlikler olarak tanımlanabilir (Tapper, 2007: 411). Bu araştırma kapsamında katılımcıların çoğu, özellikle de, bebek mevlitleri üzerinden, mevlitlerin dönüştügünü belirttiler. Katılımcılar tarafından bu dönüşüm mevlidin dini niteliğinden ve amacından sapma olarak değerlendiriliyordu. Özünde dini bir içeriği olmasa da, mevlitlerin sosyal dayanışmayı artırması beklenen bir etkinlik olması gerekirken, giderek gösterişçi tüketimin bir aracı haline geldiğinden söz ettiler. Üst sınıftan bir ailenin yaptığı bir mevlit ile yakın zamanda katıldığı bir başka mevliti karşılaştıran Dilek'in ikisi arasında kurduğu karşıtlık dikkat çekicidir:

"Bak o aile mevlit yapıyor, yani bana göre, onlarınki ne gösteriş ne şey. Onlar kutlu doğum haftasında yaparlar, köylerinde fakirlere yemek verirler. Fakir kesimi çağııırlar. Erkekler ayrı yerde, kadınlar ayrı yerde otururlar. O mevlittir."

"Ama otelde yapılan...Bebek mevliti filan..." "Ceylan yaptıydı. 5 bine kendine, 5 bine kızına Antep işi (elbise) yaptırdı. Kendi sırma giydi. 30 bin gitti herhalde. Küçük bir düğün.”

Nurgül'ün ve Nur'un bebek mevlitleriyle ilgili söyledikleri Dilek'i destekler niteliktedir: "Anne de öyle bir giyiniyor ki, sanki sahne alacakmış gibi" (Nurgül), "Bebeğin annesi direkt gelin başı yaptırmış, duvak filan bağlatmış. Abiye giymiş" (Nur). 
Gösterişli mevlitler üzerine konuşulurken, birçok katılımcının, bu tarz mevlitlere yönelik eleştirel bir tutum içinde oldukları görüldü. Örneğin Elif, dinen israfın en büyük günah olduğunu söyleyerek, bu tarz mevlitlerin, din veya dindarlık ile ilişkili olmadığını, dolayısıyla amacına aykırı olduğunu belirtti. Melek de, gösterişli mevlitlerden rahatsızlık duyduğunu dile getirenler arasındaydı ve bunun nedenini şu şekilde açıkladı: “..Ben orada dine şey yapamam, sohbeti dinleyemem, oradaki insanların hareketleri dikkatimi çeker. Hani kendimi maneviyata veremem o gösterişten. Mevlitse mevlit gibi olmalı."

Mevlitlerde yaşanan dönüşümlerden "hocaların" da üzerlerine düşeni aldığı anlaşıldı. Hocaların artık yüksek ücretler istediği, randevu ile çalıştı̆̆ ve onlar arasında sanki sahneye çıkacakmış gibi hazırlananlar olduğundan söz edildi. Şükran, "Eskiden def çalar, iki dua ederdi, ilahi söylerdi. Şimdi öyle mi, hoca geliyor, hocay1 tanıyamıorsun," ifadelerini kulland.

Mevlitlerin dönüşmesinin bazı sonuçları olduğunu da belirtmek gerekir. Kat1lımcılar bu tarz mevlitlerin bir dönem çok sık düzenlendiğini, sonradan bu sayının azaldığını belirttiler. Gül ve Mukaddes'e göre bu durum, mevlitlerin organizasyonuna yönelik beklenti düzeyinin fazla yükselmesi, bunun da mevlitleri zorlaştırması, konuklar açısından da "severek gidilmeyen" zorunlu etkinlikler haline gelmesiyle bağlantılıydı. Gül bu durumu açıklarken, önceleri mevlitler evde yapılırken insanların kalabalıktan sıkıldığını, dışarıda yapılmaya başlandığında ise özellikle de lüks/ gösterişli mevlitlerin insanları gerdiğini ve dolayısıyla, yine eskisi gibi, yani "bebek görmesinde" olduğu gibi ev ziyaretlerinin yapılmaya başladığını söyledi. Buradan hareketle, gösterişçi tüketim açısından kamuya açık mekanlarda düzenlenen mevlitlerin bir dönem araçsal hale gelmiş olsa da, sonradan giderek aşırılaşması ve belki bununla bağlantılı dini nedenlerle işlevsizleşsizleşerek ortadan kalkmaya başladığ 1 söylenebilir.

\section{Güçlenme: "Bundan on yıl önce biz böyle yapabileceğimizi tahmin bile edemezdik"}

Araştırmaya katılan kadınların neredeyse tamamı açısından üst orta sınıfa katılmak ile güçlenmek arasında bağlantı olduğunu gözlemledik. Güçlenme deneyimi, kent yaşamının daha önceleri başörtülü kadınları dışlayan homojen kamusal alanında yer alma ve sosyal yaşama katılmakla bağlantılı örnekler üzerinden açıklanmaktaydı:

"Çok değişti. On yıl önce ben tek başıma İstanbul'a gidemezdim, tek baş1ma şehir dışına çıkamazdım. Kendimize pek bir güvenimiz yoktu. Eşim izin verse de gidemezdim. Kadınlar önceden baskılanıyordu, geri plandaydı. Yani şimdi muhafazakâr dediğin kadınlar, daha aktif, her yere gidiyor. En basitinden biz bir servis tuttuk, kaplıcaya gittik, hiç kimsenin eşi buna itiraz etmedi. Bunu on sene öncesinde kabul etmezlerdi [...] Araba süren de azdı, şimdi trafiğin çoğu kadın. Ben mesela ilk ehliyeti alırken, ilk başta kayınbabam iti- 
raz etti, kadın araba mı sürecek [diye]. Şimdi değişti. Diyor iyi ki öğrendiniz. İyi ki ehliyet aldınız. Yani araba sürme ona göre erkek işiydi. Şimdi hepimiz sürüyoruz. Kızlar da sürüyor. Bundan on yıl önce biz böyle yapabileceğimizi tahmin bile edemezdik. Mesela benim on sene önce büyük kızıma yaptığım baskıyı, [bugün] küçük kızlarıma yapmam mümkün mü? " (Sevim)

"Eskiden akşam namazından sonra bayanların eve girmesi çok ayıpmış, hatta akşam namazından sonra sokaklara cin gelir derlermiş, sokakta cin olur, sizin ne işiniz olur, ne gezmesi gibi. Bayanlar, akşamları da geziyor şimdi. Spora gidiyor veya çocuklardan dolayı gündüz yoğunuz diyip, akşamları yapıyorlar toplantıyı. Eş/koca nerede? [O] evde oturuyor.” (Betül)

Burada kadınlar resmen dünyayı ele geçirmiş gibi, yani sabahtan akşama kadar, kadın arabasında geziyor." (Sevim)

Yaşanan dönüşümü başörtüsü yasağının ortadan kalkmasıyla ilişskilendirenler de oldu. Muhafazakar kadınların kamusal alandaki deneyimlerinin geleneksel toplumsal rollerin sınırlarında gezinen ve yer yer bu sınırları test eden güçlenme pratiklerine aktarıldığ 1 anlaşıliyor:

"Kadınlara özgüven verildi. Kadınlar işte, kadındır, annedir, özeldir diye." (Şükran)

“Erkekler kadınlara bir şey diyemiyor artık. Kadınlar eskiden çile çekermiş, ama şimdi hiçbir yer olmasa, sığınma evi var. Eskiden böyle şeyler yoktu. Kadın değer kazandı, boyun eğmiyor artık. Erkekler farkında, kadınlara bundan değer veriyor." (Sevim)

"Kadınlar güçlendi, erkekler de belirli bir yerde duruyorlar, susmayı biliyorlar. Hani kadınların konuşmasından dolayı mı oldu acaba. Önce sustukları için mi şiddete daha çok maruz kaldılar?” (Necla)

\section{Sonuç}

Geçmişten bugüne Türkiye'de muhafazakârlar piyasa ile ileri düzeyde bir bütünleşme imkânı elde ettiler. Muhafazakârlığı ve muhafazakârlığın neoliberal eksende dönüşümünü anlamaya yönelik çalışmalarda cinsiyet, genel olarak araçsal bir yaklaşımla tek boyutlu ve kadınları yaşanan toplumsal süreçlerin nesnesi olarak tanımlayan bir çerçevede ele alınmıştır. Bu çalışmada açılandığı üzere, üst orta sınıf muhafazakâr kimliği yeni kılan, özellikle de kadınlar için dönüşen yaşam tarzları, kimlik ve deneyim arasındaki ilişki ve gündelik hayattaki faillik biçimleridir. Gündelik pratiklerin ne tür deneyimler ürettiği, bu deneyimlerin kimlik ve öznellik açısından sonuçları yukarıda çeşitli bağlamlar içinde tartışılmıştır. Bu çerçevede, gösterişçi tüketim ve kadınlararası sosyalliklerin çeşitli biçimleri üzerinden ifade edilen güçlenmenin, üst-orta sınıf kadınlar açısından varoluş ve eyleme biçimlerini yeniden tanımladıkları ve kapsamını genişlettikleri bir güçlenme pratiği yaratma potansiyeline kuramsal açıdan bakmak gerekir. Yukarıda aktarılan güçlenme örnekleri ve genel anlamıyla güçlenme deneyimi, aile içinde kalarak ve erkeklerle müzakere edilerek gerçekleşmektedir. 
Başka bir ifadeyle, kadınların aile ve toplum içindeki ikincil konumlarını doğrudan sorgulamayan ve buna doğrudan karşı çıkmayan pratiklerin ataerkillik açısından ne anlama gelebileceğine yönelik sorgulama, ataerki içinde kalarak güçlenmenin olanağına dikkat çeker. Buna göre, kadınların, kendisini tabi kılan ataerkil yapıyla doğrudan çatışmaya girmeden, toplumsal uyum ve direniş stratejileri kullanarak belli ayrıcalıklar elde etmesi olarak tarif edilebilecek bu strateji "ataerkil pazarlık" (Kandiyoti, 2013) kavramıyla açıklanır. Bu çalışmanın kapsamında açıklanan üstorta sınıftan muhafazakâr kadınların gösterişçi tüketim pratikleri böylesi bir ataerkil pazarlığa olanak sağlamıştır.

Buna ek olarak, ataerkillik tarihsel olarak, kadınlar üzerindeki ataerkil denetimin kim tarafindan ve nasıl sağlandığına bağlı olarak farklı biçimlerde tanımlanabilir. Buna göre, bir yanda kadınların özel alandan çıkarak kamusal alana katılımının doğrudan erkek hane reisinin denetiminde olduğu özel ataerkillikten, diğer yanda ise kadınların kamusal alanda var olabildikleri, ancak eğitim, iş yaşamı gibi toplumsal yaşamın çeşitli alanlarında var olan eşitsizlikler nedeniyle ataerkil denetime tabi oldukları kamusal ataerkillikten sözedilebilir (Walby, 2016). Bu çalışma çerçevesinde yukarıda aktarılan deneyimler, üst-orta sınıf muhafazakar kadınlar açısından hane resisi erkeklerin kadınlar üzerindeki denetiminin doğrudan işlediği özel alandan kamusal alana çıkmak, eğitime ve istihdama katılımı da içeren artan ve çeşitlenen kamusal firsatlara ulaşmak anlamına gelmektedir. Başka bir ifadeyle, üst orta s1nıftan muhafazakar kadınlar açısından özel ataerkillikten kamusal aterkilliğe doğru toplumsal bir dönüşümün varlığından söz edilebilir. Her ne kadar siyasal iktidar tarafından tanımlanan yeni kamusal ataerkil söylem içinde kadınlar geleneksel rolleri ve kutsallık attfedilen nitelikleriyle tanımlanmaya devam ediyorlarsa da, ataerkil denetimin gayrişahsileşmesinin güçlenme pratikleri açısından da benzer bir sonucu doğurması beklenebilir. Yukarıda Şükran'ın, Sevim'in ve Necla'nın söyledikleri böylesi bir bağlam içinde okunabilir.

Bu çalışma, muhafazakâr kimliğin özellikle de kadın kimliği üzerinden normatif referanslar kullanarak sabitleyici bir şekilde tanımlanmasının muhafazakârlı̆̆ı, kadınların failliklerini ve sınıfı anlamayı zorlaştırdığı iddiasından hareketle üst orta sınıftan kadın kimliğini Gaziantep yerelinde kadınların gösterişçi tüketim pratikleri üzerinde dinamik süreçler içinden anlama çabasının ürünüdür. Kadınlar arası karşılaşmanın başka alanları ve tüketim pratiklerindeki çeşitliliğin bir bölümü zorunlu olarak bu makalenin kapsamı dışında bırakılmıştır. Başka bağlamlar içinde araştırmanın bu boyutlarını da tartışabilmeyi umuyoruz. Kuşkusuz, üst orta sınıftan kadınların muhafazakâr kimlik inşasındaki özne konumlarını anlamayı olanaklı kılsa da, bu araştırmanın sonuçları, muhafazakârlığın dönüştüğü tarihsel ve toplumsal sürecin ve/veya toplumsal bağlamın tamamına genellenemez. Başka bağlamlarda ve/veya ölçeklerde benzer araştırmaların yapılmasının konuyla ilgili anlayışa katkı yapacağını düşünüyoruz. 


\section{Notlar}

1 Muhafazakârlığın kavramsallaştırılmasına yönelik olarak tartaşma, bu makaleye temel oluşturan tezde geniş kapsamlı olarak yapılmaktadır. Bkz. Çöçey, 2019: 35-146.

2 Burada başörtüsü talebinin siyasal bir mücadele olarak güncelliğini yitirmesinden söz edilmektedir. Başörtüsü talebine yönelik herhangi bir iddia bu makalenin ilgi alanı ve kapsımı dışındadır.

\section{Kaynakça}

Acar, F. (1990). Türkiye'de İslamcı hareket ve kadın. İçinde: 1980’ler Türkiyesi’nde kadın baklş açısından kadınlar (Ş. Tekeli, Ed.) İstanbul: İletişim, 73-90.

Acar, F. ve Altunok, G. (2017). Toplumsal cinsiyet eşitliği taleplerini anlamak: Türkiye'de kadın hareketinin temelleri ve sınırları. İçinde: Türkiye'de refah devleti ve kadın (S. Dedeoğlu ve A. Y. Elveren, Ed.). İstanbul: İletişim, 71-102.

Adaş, B. E. (2006). The making of entrepreneurial Islam and the Islamic spirit of capitalism. Journal for Cultural Research, 10(2), 113-137.

Akdoğan, Y. (2004). Ak parti ve muhafazakâr demokrasi. İstanbul: Alfa. Aktaş, C. (2005) Cemaatten kamusal alana İslamcı kadınlar. İçinde: Modern Türkiye'de siyasi düşünce: Íslamcılık (T. Bora ve M. Gültekingil, Ed.) İstanbul: İletişim, 826-836.

Alpman, S. P. (2012). Bir tasarım, bir temenni, şimdinin "hakiki" burjuvazisi ve eleştirisi. Birikim, (278-279), 38-45.

Arat, Y. (1990). Feminizm ve İslam: Kadın ve aile dergisinin düşündürdükleri. İçinde: 1980'ler Türkiyesi 'nde kadın bakış açısından kadınlar (Ş. Tekeli, Ed.) İstanbul: İletişim, 91-101.

Arat, Y. (2016). Islamist women and feminist concerns in contemporary Turkey: Prospects for women's rights and solidarity. Frontiers: A Journal of Women Studies, 37(3), 125- 150.

Ayata, S. (2004). Bir yerel sanayi odağı olarak Gaziantep’te girişimcilik, sanayi kültürü ve ekonomik dünya ile ilişkiler. İçinde: İlhan Tekeli için armağan yazılar (S. İlkin, O. Tekelioğlu ve M. Güvenç, Ed.) İstanbul: Tarih Vakfi Yurt, 559-590.

Barbarosoğlu, F. (2013). Modernleşme sürecinde moda ve zihniyet. İstanbul: İz.

Barbarosoğlu, F. (2006). Şov ve mahrem. İstanbul: Profil.

Benedict, P. (1974). The kabul günü: Structured visiting in an Anatolian provincial town. Anthropological Quarterly, 47(1), 28-47.

Beneton, P. (2016). Muhafazakarlık (C. Akalın, Çev.) İstanbul: İletişim.

Bilici, M. (2017). İslam'ın bronzlaşan yüzü: Caprice hotel örnek olayı. İçinde: İslam'ın yeni kamusal yüzleri (N. Göle, Ed.) İstanbul: Metis, 216-237.

Bora, T. (2017). Cereyanlar: Türkiye'de siyasi ideolojiler. İstanbul: İletişim.

Bora, T. (1998). Türk sağının üç hali: Milliyetçilik, muhafazakârlık, İslamcılık. İstanbul: İletişim.

Bourdieu, P. (2015). Ayrım: Beğeni yargısının toplumsal eleştirisi. (D. Fırat ve G. Berkkurt, Çev.) Ankara: Heretik.

Buğra, A.ve Savaşkan, O. (2015). Türkiye'de yeni kapitalizm: Siyaset, din ve iş dünyası. İstanbul: İletişim.

Buğra, A. (1998). Class, culture and the state: An analysis of interest representation by two Turkish 
business associations. Middle Eastern Studies, 30(4), 521-539).

Buğra, A. (2002). Labour, capital and religion: Harmony and conflict among the constituency of political Islam in Turkey. Middle Eastern Studies, 38(2), 187-204. https://doi.org/10.1080/714004454.

Cengiz, K. (2013). 'Yav işte fabrikalaşak', Anadolu sermayesinin oluşumu: Kayseri Hacılar örneği. İstanbul: İletişim.

Coşar, S. ve Yeğenoglu, M. (2009). The neoliberal restructuring of Turkey's social security system. Monthly Review, 60(11), 39-49.

Creswell, J. W. (2017). Nitel araştırmacılar için 30 temel beceri. (H. Özcan, Çev.), Ankara: Anı.

Çayır, K. (2017). İslamcı bir sivil toplum örgütü: Gökkuşağı İstanbul Kadın Platformu. İçinde: İslamıın yeni kamusal yüzleri (N. Göle, Ed.) İstanbul: Metis, 216-237.

Çiğdem, A. (2013). Sunuş. İçinde: Modern Türkiye'de siyasi düşünce Cilt 5: Muhafazakârlık (T. Bora ve M. Gültekingil, Ed.) İstanbul: İletişim, 13-19.

Çur, A. (2018). Kadınlar: Taşranın yurtsuzları. İçinde: Taşraya bakmak (T. Bora, Ed.) İstanbul: İletişim, 116-135.

Demiralp, S. (2009). The rise of Islamic capital and the decline of Islamic radicalism in Turkey. Comparative Politics, 41(3), 315-335.

Durak, Y. (2012). Dindar muhafazakâr burjuvazi ve yukarıdan dindarlık. Birikim, (278-279), 46-47.

Durakbaşa, A. (2010). Taşra burjuvazisinin tarihsel kökenleri. Toplum ve Bilim, (118), 6-39.

Erkilet, A. (2012). Mahremiyetin dönüşümü: Değer, taklit ve gösteriş tüketimi bağlamında“İslami” moda dergileri. Birey ve Toplum, 2(4), 27-40.

Geniş, Ş.ve Adaş, E. B. (2011). Gaziantep kent nüfusunun demografik ve sosyoekonomik: Saha araştırmasından notlar. Gaziantep Üniversitesi Sosyal Bilimler Dergisi, 10(1), 293-321.

Goffmann, E. (2014). Günlük yaşamda benliğin sunumu. (3. Baskı). (B. Cezar, Çev.) İstanbul: Metis.

Gökarıksel, B. ve Secor, A. J. (2010). Between fashion and tesettür: Marketing and consuming women's Islamic dress. Journal of Middle East Women's Studies, 6(3), 118-148.

Gökarıksel, B. ve Secor, A. J. (2008). New transnational geographies of Islamism, capitalism and subjectivity: The veiling-fashion industry in Turkey. Area, 41(1), 6-18.

Gökgöz, G. (2016). Gaziantep: muhafazakâr bir taşra kenti ve emekçi kadınların zihin halleri. İçinde: Yerli ve milli gündelik hayat (M. Yücebaş, Ed.) İstanbul: İletişim, 105-153.

Göle, N. (2017). Modernist kamusal alan ve İslami ahlak. İçinde: İslamıın yeni kamusal yüzleri. (N. Göle, Ed.) İstanbul: Metis, 19-40.

Göle, N. (2016). Modern mahrem (13. Basım). Metis.

Gündüz Hoşgör, A. (2011). Kadın istihdamı üzerinden marka şehir Gaziantep'i yeniden okumak. İçinde: 'Ta ezelden taşkındır... 'Antep. (M. N. Gültekin, Ed.) İstanbul: İletişim, 491-512.

Haenni, P. (2011). Piyasa İslamı. (L. Ünsaldı, Çev.), Ankara: Heretik.

Hirsh, E., Olson, G. A. ve Harding, S. (1995). Starting from marginalized lives: A conversation with Sandra Harding", JAC, 15(2), 193-225.

Hoşgör, E. (2013). İslami sermaye. Neoliberalizm, İslamcı sermayenin yükselişi ve AKP. İçinde. (N. Balkan, E. Balkan ve A. Öncü Ed.) İstanbul: Yordam Kitap, 215-250.

Kandiyoti, D. (2013). Cariyeler, bacılar, yurttaşlar: Kimlikler ve toplumsal dönüşümler İstanbul: Metis.

Karadağ, M. (2011). Gaziantep’te kentsel mekânın ve kültürel coğrafyanın değişimi. İçinde: 'Ta ezelden taşkındır...'Antep. (M. N. Gültekin, Ed.) İstanbul: İletişim, 393-413. 
Karadağ, M. (2010). Taşra kentlerinde yaşam tarzları alanı: Kültür ve ayrım. Toplum ve Bilim, (118): $39-58$.

Karakaya, H. (2018). Türkiye'de dindar burjuva ve kadın. Firat Üniversitesi Sosyal Bilimler Dergisi, 28(2), 211-229. https://doi.org/10.18069/firatsbed.460944.

Köse, E. (2014). Sessizliği söylemek: Dindar kadın edebiyatı, cinsiyet ve beden. İstanbul: İletişim.

Mardin, Ş. (2008). Türkiye'de din ve siyaset. İstanbul: İletişim.

Meşe, İ. (2015). İslami bir moda dergisi örneğinde moda ve tesettür: Ne türden bir birliktelik? Fe Dergi, $7(1), 146-158$.

Mosedale, S. (2005). Assessing women's empowerment: towards a conceptual framework. Journal of International Development, 17(2), 243-257.

Navaro-Yaşın, Y. (2017). Kimlik piyasası: Metalar, İslamcılık, laiklik. İçinde: Kültür fragmanları: Türkiye'de gündelik hayat (D. Kandiyoti ve A. Saktanber Ed.) 4. Bask1, İstanbul: Metis, 229-258.

Özcan, G. B.ve Çokgezen, M. (2003). Limits to alternative forms of capitalization: The case of Anatolian holding companies. World Development, 31(12), 2061-2084. https://doi.org/10.1016/j. worlddev.2003.04.006.

Öztürk, Ö. (2013). Türkiyède İslamcı büyük burjuvazi. İçinde: Neoliberalizm, İslamcı sermayenin yükselişi ve AK. İçinde. (N. Balkan, E. Balkan ve A. Öncü Ed.) İstanbul: Yordam, 181-214.

Rubin, M. (2005). Green money, Islamist politics in Turkey. Middle East Quarterly, 12(1), 13-23.

Sandıkçı, Ö. ve Ger, G. (2007). Constructing and representing the Islamic consumer in Turkey. Fashion Theory, 11(2/3), 189-210.

Savran, S. (2013). İslamcılık, AKP, burjuvazinin iç savaşı. İçinde: Neoliberalizm, İslamcı sermayenin yükselişi ve AKP. İçinde. (N. Balkan, E. Balkan ve A. Öncü Ed.) İstanbul: Yordam, 53-142.

Scott, W. J. (2013). Feminist tarihin peşinde. İstanbul: Bgst.

Tapper, N. (2007). Ziyaret: Gender, movement, and Exchange in a Turkish community. In: Muslim Travellers: Pilgrimage, migration, and the religious imagination (D. F. Eickelman and J. Piscatori, Ed.) London and New York: Routledge, 396-425.

Taşkın, Y. (2017). AKP devri: Türkiye siyaseti, İslâmcılık, Arap baharı. İstanbul: İletişim.

Tuğal, C. (2011). Pasif devrim: İslami muhalefetin düzenle bütünleşmesi. İstanbul: Koç Üniversitesi.

Uysal, A. (2011). Antep’te siyaset: Yerli, muhafazakâr, sermayedar. İçinde: 'Ta ezelden taşkındır...' Antep. (M. N. Gültekin, Ed.) İstanbul: İletişim, 445-467.

Veblen, T. (2015). Aylak sınıfin teorisi. (E. Kırmızıaltın ve H. Bilir, Çev.) Ankara: Heretik.

Walby, S. (2016). Patriyarka kuramı. (H. Osmanoğlu, Çev.) Ankara: Dipnot.

Yankaya, D. (2012). 28 Şubat, İslami burjuvazinin iktidarı yolunda bir milat. Birikim, (278-279), 29-37.

Yankaya, D. (2014). Yeni İslami burjuvazi: Türk modeli. (M. I. Durmaz, Çev.) İstanbul: İletişim.

Yavuz, M. H. (2006). Introduction: The role of new bourgeoisie in the transformation of Turkish Islamic movement. The emergence of a new Turkey: Islam, democracy, and the Ak Parti içinde (M. H. Yavuz, Ed.) Utah: The University of Utah, 1-19.

Yelsalı Parmaksız, P. M. (2017). Türkiye'nin modernleşmesinde kadınlar, 1839'dan günümüze. Ankara: İmge.

Y1lmaz, Z. (2015). Dişil dindarlı. İstanbul: İletişim.

Yücebaş, S. (2012). Türkiye'de muhafazakârlığın gündelik yaşam estetiği. İnsanbilim Dergisi, 1(2), 62-80. 
Zürcher, J. E. (2013). Terakkiperver Cumhuriyet Fırkası ve siyasal muhafazakârlık. İçinde: Modern Türkiye'de siyasi düşünce: Muhafazakârlık (T. Bora ve M. Gültekingil, Ed.) İstanbul: İletişim, 4053.

\section{Elektronik kaynaklar}

Adaş, B. E. (2003). Profit and the prophet: Culture and politics of Islamic entrepreneurs in Turkey. [Doktora Tezi, University of Illinois].https://www.ideals.illinois.edu/handle/2142/86198. Erişim Tarihi: 28/02/2021.

Balkanlığlu, E. (2014). Türkiye'de muhafazakâr kadın modernleşmesi ve İslami moda dergilerindeki yeni muhafazakâr kadın. [Yüksek Lisans Tezi, İstanbul Üniversitesi]. http://nek.istanbul.edu. tr:4444/ekos/TEZ/ET001011.pdf. Erişim Tarihi: 28/02/2021.

Doherty, S. J. (2007). Islamic economics: The Islamic bourgeoisie and the imagined community. [Yüksek Lisans Tezi, Boğaziçi Üniversitesi]. https://dokumen.tips/documents/islamic-economicsthe-islamic-bourgeoisie-and-the-imagined-community-islami.html. Erişim Tarihi: 28/02/2021.

Özoral, B. (2011). Economic engagement of religious ethics in a global economy: The rise of Islamic capital in Central Anatolia as a new economic power, 1980-present. [Doktora Tezi, McGill University]. https://escholarship.mcgill.ca/concern/theses/0c483p38v. Erişim Tarihi: 28/02/2021. 